\title{
Transmission, diversity and virulence factors of Streptococcus mutans genotypes
}

\author{
Marcelo Henrique Napimoga, Jose Francisco Höfling, Marlise Inez Klein, \\ Regianne Umeko Kamiya and Reginaldo Bruno Gonçalves
}

Department of Oral Diagnostics, Faculty of Dentistry of Piracicaba, University of Campinas, Piracicaba, São Paulo, Brazil

(Received 3 December 2004 and accepted 9 April 2005)

\begin{abstract}
Dental caries is an infectious and transmissible disease, in which many genetic, environmental and behavioral risk factors interact. The mutans streptococci (MS), mainly Streptococcus mutans and Streptococcus sobrinus are the microorganisms most strongly associated with this disease. The main virulence factors associated with MS cariogenicity include adhesion, acidogenicity and acid tolerance. These properties work together to modify the physico-chemical properties of the biofilm, resulting in ecological changes in the form of increased proportions of S. mutans and other acidogenic and aciduric species. In addition, reports of higher numbers of S. mutans genotypes with increased virulence in caries-active subjects suggest the importance of microenvironmental factors in increasing the risk of caries. This review focuses on the transmission and establishment of different genotypes of $S$. mutans and the role they play in the development of dental caries. (J. Oral Sci. 47, 59-64, 2005)
\end{abstract}

Keywords: Streptococcus mutans; dental caries; genotypes; mutacin; glucosyltransferase; review.

Correspondence to Dr. Reginaldo B. Gonçalves, Department of Oral Diagnostics, Faculty of Dentistry of Piracicaba, University of Campinas, Piracicaba, São Paulo, Brazil Av. Limeira, 901 Areião - Piracicaba, São Paulo, Brazil

13414-903 - Caixa Postal 052

Tel: + 55-19-3412-5379

Fax: + 55-19-3412-5218

E-mail: reginald@fop.unicamp.br

\section{Introduction}

Dental caries is a transmissible infectious disease in which mutans streptococci (MS) play the major role. As in many infectious diseases, colonization by pathogens is required before the disease can occur. MS are generally considered to be the principal etiological agent of dental caries (1).

There is a range of virulence factors important for the establishment of MS in the complex microbial community of dental biofilm. Studies of the virulence factors of $S$. mutans and their correlation with species biodiversity are fundamental to understanding the role played by colonization by different genotypes in the same individual, and the expression of characteristics that may or may not influence their virulence capacity and survival ability under different environmental conditions.

\section{Colonization, transmissibility and stability of $S$. mutans in the oral cavity}

Studies using phenotyping and/or genotyping methods strongly suggest that the mother is the major primary source of infection for children who carry S. mutans and/or S. sobrinus strains (2-10), and the saliva is the principal vehicle by which transfer of MS may occur (10-12). However, detection of genotypes that are not found in children's mothers or other family members indicates that S. mutans and/or S. sobrinus may also be acquired from other sources $(5,7,8,10,12)$.

Furthermore, variability in transmission can be associated with children's individual susceptibilities, including the period defined as the window of infectivity (13), which was reported to occur earlier in Brazilian children $(14,15)$; the number of erupted teeth $(13,15,16)$; the emergence of 
molars (13); the presence of enamel hypoplasia (17); sucrose consumption (14); the action of nonspecific factors of the salivary and mucosal immune systems (3); and immunological conditions in children (18).

It has been observed that children harbor one to five distinct genotypes of MS at different ages (4-7,10,12,1921). The MS genotypic diversity in four sampling sites (saliva, tongue dorsum, alveolar ridge mucosa, dental biofilm) from children's oral cavities was shown to be homogeneous; however, the dental biofilm was an important site given the greater number of MS genotypes and strains isolated (10). Studies of the initial colonization by MS indicate that these bacteria require non-shedding tooth surfaces to become established in the oral cavity (16). More sensitive methods using DNA specific probes indicate that the retentive surfaces of the tongue dorsum may function as a reservoir for posterior tooth colonization (22).

Nevertheless, few data are available about the stability of the genotypes detected at the time of initial acquisition. Previous studies suggested that early colonizing MS strains might be stable in the mouth for many years, although some genotypes detected in childhood could not be recovered in later years $(8-10,19,23)$.

Klein et al. (10) identified a total of 52 distinct genotypes in children, but mothers transmitted only 16 of them. However, a tendency toward effective stability of genotypes transmitted by mothers was observed (10). One explanation for this selective colonization is that the immune response to a successfully colonizing maternal genotype may interfere with colonization of other genotypes, making colonization less likely $(3,18)$. The maternal role in infection also suggests that the contacts responsible for salivary transmission of these organisms can also provide frequent immunological exposure to bacterial antigens (18). The mechanisms of action of salivary IgA antibodies against MS include interference with their sucrose-independent and sucrose-dependent attachments to, and accumulation on, tooth surfaces, as well as possible inhibition of their metabolic activities (24).

Alaluusua et al. (25) demonstrated a high degree of homology between MS strains recovered among members of the same family, indicating both vertical and horizontal routes of transmission, and persistent colonization by early acquired MS until young adulthood. It was also shown that isolates that had similar genetic fingerprints (transmitted strains) had similar expression of glucosyltransferase (GTF). One case was reported of a similar S. mutans genotype colonizing two children from unrelated families attending the same Brazilian nursery (12). In addition, a study of 39 Japanese children from a day nursery found that six of them shared the same strain type of MS (26). Taken together, these results suggest that horizontal transmission may also occur.

Some previous work has shown greater genetic variability of $S$. mutans in nursing-bottle caries than in healthy children; however, a positive relationship between caries activity and the genetic diversity of $S$. mutans is still controversial. Alaluusua et al. (4) suggested that cariesactive children with high sucrose consumption carry greater ribotype diversity of MS compared with caries-free children. On the other hand, Kreulen et al. (21) showed a negative correlation between caries activity and genotypic diversity.

The ability of bacteria to survive and persist in a given environment will depend, in part, on their inherent genetic plasticity, which determines their ability to respond to fluctuating local environmental conditions or stresses (27). The microbiota resident in the oral biofilm are subjected to many variable environmental stresses, including the availability or lack of nutrients, acidic $\mathrm{pH}$, and exposure to organic acids $(28,29)$. Paddick et al. (30) showed that the proportions of MS and lactobacilli were elevated in the biofilm of caries-active subjects, while A. naeslundii isolates formed a significantly greater proportion of the microbiota in samples from caries-free subjects. These observations support the assertion that the biofilm samples from the two subject populations were exposed to different environments and, consequently, to different stresses.

In a recent study of young adults, Redmo-Emanuelsson et al. (31) found a maximum of seven genotypes in subjects who had previous caries experience. This study is consistent with our findings of a maximum of eight genotypes in caries-active young subjects using AP-PCR (32). The existence of several genotypes in biofilm could merely be a consequence of favorable circumstances for MS in biofilm, but it is possible that the simultaneous action of different genotypes with distinct virulence potential further increases the risk of caries. Nascimento et al. (33) found that $S$. mutans was more prevalent in coronal than root dental biofilm, but no difference was found between root and coronal caries lesions. Furthermore, the maximum number of $S$. mutans genotypes found together at a specific site was five and the same genotype could be found at more than one oral site.

\section{Adhesion}

Biofilm development occurs in two distinct phases: during the first, bacterial surface proteins interact with host or bacterial products adsorbed on the tooth surface. In the second phase, biofilm forms as bacteria accumulate by aggregation with the same or other species and produce 
an extracellular polysaccharide matrix (34). Genetic differences may relate to differences in virulence between MS strains. One important characteristic of $S$. mutans in promoting caries development is the ability to adhere firmly to the tooth surface in the presence of sucrose (25), and this adherence is mediated mainly by the enzymatic action of the GTF enzymes $(1,35)$. These enzymes are considered fundamental for the virulence of $S$. mutans in the pathogenesis of dental caries (36). Previous research has shown differences in virulence factors among $S$. mutans isolates $(32,37,38)$. Differences in the synthesis of water insoluble-glucan (WIG) or biofilm formation between genotypes could be associated with different levels of virulence. This is important, since it has been demonstrated that WIG produced from sucrose modifies the physicochemical properties of dental plaque, including low inorganic concentrations of calcium, phosphorus and fluoride (39) and increased porosity of the dental plaque matrix (40), making it more cariogenic.

Bacteria are known to regulate diverse physiological processes through a mechanism called quorum sensing (41). The com system, which controls genetic competence development in response to the concentration of the competence-stimulating peptide, is also involved in biofilm formation and the biofilm architecture of S. mutans. This cell-cell signaling system involves several gene products encoded by cslAB (comAB) (42) and comCDE (43). This quorum-sensing system functions optimally when the cells are living in actively growing biofilms (43), suggesting that the cell-cell signaling system might play a role in the formation of S. mutans biofilms. A recent study described the effects of mutations in several com loci with regard to biofilm formation. The results clearly showed that inactivation of any one of the genes encoding the components of the quorum-sensing system, in particular $\operatorname{com} C$, results in the formation of an abnormal biofilm (44). Recent studies have shown that luxS is involved in global regulation of physiological functions and virulence. Also, luxS inactivation resulted in decreased expression of several genes that encode membrane-associated proteins, including $B r p A$ and $F f h$, which have been shown to play roles in envelope integrity and acid tolerance (45).

Other bacterial components associated with the accumulation phase of MS are proteins that bind glucan. At least three $S$. mutans glucan binding proteins (Gbp) have been identified: GbpA (46), GbpB (47), and GbpC (48).

Although over the years numerous surface or secreted products of MS have been proposed as vaccine antigen candidates, attention has recently focused on three protein antigens: the surface fibrilar adhesins known as $\mathrm{AgI} / \mathrm{II}$ (or SpaP, PAc), the glucosyltransferases and the glucan- binding proteins (49). Numerous experiments in a variety of animal models comprising rodents and primates have demonstrated the induction of salivary S-IgA and circulating IgG antibodies to MS antigens by oral or intranasal immunization with AgI/II, GTF or Gbps (24,50-52). Immunization of mice with synthetic peptides (residues 301-319) from the alanine-rich region of antigen I/II suppressed tooth colonization with $S$. mutans (53). Intranasal immunization with antigen I/II, coupled with the cholera toxin B subunit, suppressed colonization of mouse teeth by $S$. mutans (53). Although the basic principle of immune protection from dental caries caused by MS has been established in pre-clinical studies, the effective application of this approach to humans needs further refinement (54). Furthermore, in experimental infection of rats, systemic or mucosal immunization with $\mathrm{GbpB}$ induced protective immunity to dental caries, indicating that GbpB may be an important target for the development of caries vaccines (55).

\section{Mutacin}

The role of mutacins in vivo is unclear, however the antimicrobial activity of these substances may confer an ecological advantage for the producing strain in bacterial communities such as dental biofilm (56), and they may also be important for the establishment of $S$. mutans in vivo $(56,57)$.

Mutacins are peptide or protein antibiotics that are mainly bactericidal for other bacteria of the same or closely related species, as well as for other Gram-positive microorganisms, and are likely to confer an ecological advantage in diverse bacterial communities such as dental biofilm (56). The relationship between caries activity and the higher synthesis of some virulence factors by different genotypes of $S$. mutans has been demonstrated in the literature $(32,37)$.

The mutacin activity of $S$. mutans may facilitate the transmission of the species between mother and child and increase the ratio of this species in the dental biofilm, contributing to increased risk of caries (6). However, some studies found no association between the inhibitory spectrum of mutacins and infecting levels of MS or caries incidence, suggesting that mutacin production may not be relevant in the ability of $S$. mutans to colonize the host and induce disease $(58,59)$.

In a recent study, Kamiya et al. (60) showed distinct mutacin production profiles between $S$. mutans isolated from caries-active and caries-free individuals, which can be related to different colonization profiles described in these individuals. Mutacins could play an important biological role in the regulation and composition of dental 
biofilm due to their synergistic or antagonistic activity, suggesting that wide spectrum mutacins may be more important in the colonization and stabilization of this cariogenic species, mainly in the stable niche of highly complex microbial activity (60).

\section{Conclusion}

The identification of the source of MS transmission is essential to the development of strategies for the prevention of dental caries. The early acquisition of MS by infants occurs mainly via the mother's saliva, and probably also by other sources of transmission. Immunological interception of the initial attempts of MS to colonize the tooth surface would seem to be the preferred vaccine strategy. Successful establishment of MS in infancy appears to lead to colonization of the permanent dentition by MS and their persistence into adulthood. In addition to environmental and host factors, identification of specific pathogenic genotypes of $S$. mutans that may be more virulent colonizers might predict sites that are more susceptible to disease.

\section{References}

1. Loesche WJ (1986) Role of Streptococcus mutans in human dental decay. Microbiol Rev 50, 353-380

2. van Houte J, Gibbs G, Butera C (1982) Oral flora of children with "nursing bottle caries". J Dent Res $61,382-385$

3. Li Y, Caufield PW (1995) The fidelity of initial acquisition of mutans streptococci by infants from their mothers. J Dent Res 74, 681-685

4. Alaluusua S, Mattö J, Grönroos L, Innila S, Torkko $\mathrm{H}$, Asikainen S, Jousimies-Somer H, Saarela M (1996) Oral colonization by more than one clonal type of mutans streptococcus in children with nursing-bottle dental caries. Arch Oral Biol 41, $167-173$

5. Emanuelsson IR, Li Y, Bratthall D (1998) Genotyping shows different strains of mutans streptococci between father and child and within parental pairs in Swedish families. Oral Microbiol Immunol 13, 271-277

6. Grönroos L, Saarela M, Mattö J, Tanner-Salo U, Vuorela A, Alaluusua S (1998) Mutacin production by Streptococcus mutans may promote transmission of bacteria from mother to child. Infect Immun 66, 2595-2600

7. Kozai K, Nakayama R, Tedjosasongko U, Kuwahara S, Suzuki J, Okada M, Nagasaka N (1999) Intrafamilial distribution of mutans streptococci in Japanese families and possibility of father-to-child transmission. Microbiol Immunol 43, 99-106

8. Emanuelsson IR, Thornqvist E (2000) Genotypes of mutans streptococci tend to persist in their host for several years. Caries Res 34, 133-139

9. Köhler B, Lundberg AB, Birkhed D, Papapanou PN (2003) Longitudinal study of intrafamilial mutans streptococci ribotypes. Eur J Oral Sci 111, 383-389

10. Klein MI, Florio FM, Pereira AC, Höfling JF, Gonçalves RB (2004) Longitudinal study of transmission, diversity, and stability of Streptococcus mutans and Streptococcus sobrinus genotypes in Brazilian nursery children. J Clin Microbiol 42, 4620-4626

11. Köhler B, Bratthall D (1978) Intrafamilial levels of Streptococcus mutans and some aspects of the bacterial transmission. Scand J Dent Res 86, 35-42

12. Mattos-Graner RO, Li Y, Caufield PW, Duncan M, Smith DJ (2001) Genotypic diversity of mutans streptococci in Brazilian nursery children suggests horizontal transmission. J Clin Microbiol 39, 23132316

13. Caufield PW, Cutter GR, Dasanayake AP (1993) Initial acquisition of mutans streptococci by infants: evidence for a discrete window of infectivity. J Dent Res 72, 37-45

14. Mattos-Graner RO, Zelante F, Line RC, Mayer MP (1998) Association between caries prevalence and clinical, microbiological and dietary variables in 1.0 to 2.5-year-old Brazilian children. Caries Res $32,319-323$

15. Florio FM, Klein MI, Pereira AC, Gonçalves RB (2004) Time of initial acquisition of mutans streptococci by human infants. J Clin Pediatr Dent 28, 303-308

16. Berkowitz RJ, Jordan HV, White G (1975) The early establishment of Streptococcus mutans in the mouths of infants. Arch Oral Biol 20, 171-174

17. Li Y, Navia JM, Caufield PW (1994) Colonization by mutans streptococci in the mouths of 3- and 4year-old Chinese children with or without enamel hypoplasia. Arch Oral Biol 39, 1057-1062

18. Smith DJ, King WF, Akita H, Taubman MA (1998) Association of salivary immunoglobulin A antibody and initial mutans streptococcal infection. Oral Microbiol Immunol 13, 278-285

19. Caufield PW, Walker TM (1989) Genetic diversity within Streptococcus mutans evident from chromosomal DNA restriction fragment polymorphisms. J Clin Microbiol 27, 274-278

20. Kulkarni GV, Chan KH, Sandham HJ (1989) An investigation into the use of restriction endonuclease 
analysis for the study of transmission of mutans streptococci. J Dent Res 68, 1155-1161

21. Kreulen CM, de Soet HJ, Hogeveen R, Veerkamp JSJ (1997) Streptococcus mutans in children using nursing bottles. ASDC J Dent Child 64, 107-111

22. Tanner ACR, Milgrom PM, Kent R Jr., Mokeem SA, Page RC, Riedy CA, Weinstein P, Bruss J (2002) The microbiota of young children from tooth and tongue samples. J Dent Res 81, 53-57

23. Alaluusua S, Alaluusua SJ, Karjalainen J, Saarela M, Holttinen T, Kallio M, Hölttä P, Torkko H, Relander P, Asikainen S (1994) The demonstration by ribotyping of the stability of oral Streptococcus mutans infection over 5 to 7 years in children. Arch Oral Biol 39, 467-471

24. Russell MW, Hajishengallis G, Childers NK, Michalek SM (1999) Secretory immunity in defense against cariogenic mutans streptococci. Caries Res 33, 4-15

25. Alaluusua S, Grönroos L, Zhu X, Saarela M, Mattö J, Asikainen S, Fukushima K (1997) Production of glucosyltransferases by clinical mutans streptococcal isolates as determined by semiquantitative cross-dot assay. Arch Oral Biol 42, 417-422

26. Tedjosasongko U, Kozai K (2002) Initial acquisition and transmission of mutans streptococci in children at day nursery. ASDC J Dent Child 69, 284-288

27. Dobrindt U, Hacker J (2001) Whole genome plasticity in pathogenic bacteria. Curr Opin Microbiol 4, 550-557

28. Carlsson J (1989) Microbial aspects of frequent intake of products with high sugar concentrations. Scand J Dent Res 97, 110-114

29. Nascimento MM, Lemos JA, Abranches J, Gonçalves RB, Burne RA (2004) Adaptive acid tolerance response of Streptococcus sobrinus. J Bacteriol 186, 6383-6390

30. Paddick JS, Brailsford SR, Kidd EA, Gilbert SC, Clark DT, Alam S, Killick ZJ, Beighton D (2003) Effect of the environment on genotypic diversity of Actinomyces naeslundii and Streptococcus oralis in the oral biofilm. Appl Environ Microbiol 69, 64756480

31. Redmo Emanuelsson IM, Carlsson P, Hamberg K, Bratthall D (2003) Tracing genotypes of mutans streptococci on tooth sites by random amplified polymorphic DNA (RAPD) analysis. Oral Microbiol Immunol 18, 24-29

32. Napimoga MH, Kamiya RU, Rosa RT, Rosa EA, Höfling JF, Mattos-Graner RO, Gonçalves RB (2004) Genotypic diversity and virulence traits of
Streptococcus mutans in caries-free and cariesactive individuals. J Med Microbiol 53, 697-703

33. Nascimento MM, Höfling JF, Gonçalves RB (2004) Streptococcus mutans genotypes isolated from root and coronal caries. Caries Res 38, 454-463

34. Kolenbrander PE (2000) Oral microbial communities: biofilms, interactions, and genetic systems. Annu Rev Microbiol 54, 413-437

35. Kuramitsu HK (1993) Virulence factors of mutans streptococci: role of molecular genetics. Crit Rev Oral Biol Med 4, 159-176

36. Yamashita Y, Bowen WH, Burne RA, Kuramitsu HK (1993) Role of the Streptococcus mutans gtf genes in caries induction in the specific-pathogen-free rat model. Infect Immun 61, 3811-3817

37. Mattos-Graner RO, Smith DJ, King WF, Mayer MP (2000) Water-insoluble glucan synthesis by mutans streptococcal strains correlates with caries incidence in 12- to 30-month-old children. J Dent Res 79, 1371-1377

38. Mattos-Graner RO, Napimoga MH, Fukushima K, Duncan MJ, Smith DJ (2004) Comparative analysis of Gtf isozyme production and diversity in isolates of Streptococcus mutans with different biofilm growth phenotypes. J Clin Microbiol 42, 4586-4592

39. Cury JA, Rebello MAB, Del Bel Cury AA (1997) In situ relationship between sucrose exposure and the composition of dental plaque. Caries Res 31, 356-360

40. Zero DT, Fu J, Anne KM, Cassata S, McCormack SM, Gwinner LM (1992) An improved intra-oral enamel demineralization test model for the study of dental caries. J Dent Res 71 (Spec), 871-878

41. Kleerebezem M, Quadri LE, Kuipers OP, de Vos WM (1997) Quorum sensing by peptide pheromones and two-component signal-transduction systems in Gram-positive bacteria. Mol Microbiol 24, 895904

42. Petersen FC, Scheie AA (2000) Genetic transformation in Streptococcus mutans requires a peptide secretion-like apparatus. Oral Microbiol Immunol 15, 329-334

43. Li YH, Lau PCY, Lee JH, Ellen RP, Cvitkovitch DG (2001) Natural genetic transformation of Streptococcus mutans growing in biofilms. J Bacteriol 183, 897-908

44. Li YH, Tang N, Aspiras MB, Lau PC, Lee JH, Ellen RP, Cvitkovitch DG (2002) A quorum-sensing signaling system essential for genetic competence in Streptococcus mutans is involved in biofilm formation. J Bacteriol 184, 2699-2708 
45. Wen ZT, Burne RA (2004) LuxS-mediated signaling in Streptococcus mutans is involved in regulation of acid and oxidative stress tolerance and biofilm formation. J Bacteriol 186, 2682-2691

46. Russell RR (1979) Glucan-binding proteins of Streptococcus mutans serotype c. J Gen Microbiol 112, 197-201

47. Smith DJ, Akita H, King WF, Taubman MA (1994) Purification and antigenicity of a novel glucanbinding protein of Streptococcus mutans. Infect Immun 62, 2545-2552

48. Sato Y, Yamamoto Y, Kizaki H (1997) Cloning and sequence analysis of the $g b p C$ gene encoding a novel glucan-binding protein of Streptococcus mutans. Infect Immun 65, 668-675

49. Russell MW, Childers NK, Michalek SM, Smith DJ, Taubman MA (2004) A caries vaccine? The state of the science of immunization against dental caries. Caries Res 38, 230-235

50. Childers NK, Tong G, Li F, Dasanayake AP, Kirk K, Michalek SM (2002) Humans immunized with Streptococcus mutans antigens by mucosal routes. J Dent Res 81, 48-52

51. Koga T, Oho T, Shimazaki Y, Nakano Y (2002) Immunization against dental caries. Vaccine 20, 2027-2044

52. Smith DJ (2002) Dental caries vaccines: prospects and concerns. Crit Rev Oral Biol Med 13, 335-349

53. Takahashi I, Okahashi N, Matsushita K, Tokuda M, Kanamoto T, Munekata E, Russell MW, Koga $\mathrm{T}$ (1991) Immunogenicity and protective effect against oral colonization by Streptococcus mutans of synthetic peptides of a streptococcal surface protein antigen. J Immunol 146, 332-336

54. Mattos-Graner RO, Smith DJ (2004) The vaccination approach to control infections leading to dental caries. Braz J Oral Sci 11, 595-608

55. Smith DJ, Taubman MA (1996) Experimental immunization of rats with a Streptococcus mutans 59-kilodalton glucan-binding protein protects against dental caries. Infect Immun 64, 3069-3073

56. Balakrishnan M, Simmonds RS, Kilian M, Tagg JR (2002) Different bacteriocin activities of Streptococcus mutans reflect distinct phylogenetic lineages. J Med Microbiol 51, 941-948

57. Hamada S, Ooshima T (1975) Production and properties of bacteriocins (mutacins) from Streptococcus mutans. Arch Oral Biol 20, 641-648

58. Alaluusua S, Takei T, Ooshima T, Hamada S (1991) Mutacin activity of strains isolated from children with varying levels of mutans streptococci and caries. Arch Oral Biol 36, 251-255

59. Longo PL, Mattos-Graner RO, Mayer MPA (2003) Determination of mutacin activity and detection of mutA genes in Streptococcus mutans genotypes from caries-free and caries-active children. Oral Microbiol Immunol 18, 144-149

60. Kamiya RU, Napimoga MH, Rosa RT, Höfling JF, Gonçalves RB (2005) Mutacin production in Streptococcus mutans genotypes isolated from caries-affected and caries-free individuals. Oral Microbiol Immunol 20, 20-24 